\title{
SKRINING STUNTING DAN PERKEMBANGAN PADA ANAK PRA SEKOLAH DI TK PERTIWI SALEPPA MAJENE
}

\author{
STUNTING AND CHILDREN DEVELOPMENT SCREENING \\ IN PRE SCHOOLS AT TK PERTIWI SALEPPA MAJENE
}

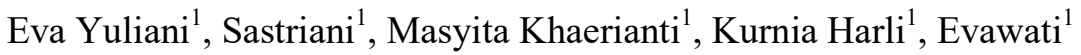

${ }^{1}$ Universitas Sulawesi Barat, J1. Sultan Hasanuddin Majene eva.yuliani@unsulbar.ac.id

\begin{abstract}
Abstrak
Masa balita merupakan masa yang rawan mengalami masalah kurang gizi, dan perkembangan, hal tersebut dikarenakan pada masa balita tubuh mengalami pertumbuhan dan perkembangan yang relatif cepat dibandingkan masa-masa yang lain. Skrining pertumbuhan dan perkembangan anak pra sekolah merupakan salah satu upaya meningkatkan kualitas anak. Tujuan kegiatan ini adalah untuk mengidentifikasi pertumbuhan dan perkembangan anak pra sekolah. Hasil pelaksanaan skrining pertumbuhan (stunting) TB/U didapatkan jumlah anak yang mengalami stunting adalah 25 orang (51\%), dan yang normal sebanyak 24 orang (49\%), sedangkan pemeriksaan perkembangan didapatkan 17 orang (34,7\%) mengalami penyimpangan, 11 orang $(22,4 \%)$ mengalami perkembangan yang meragukan dan 21 orang $(42,9 \%)$ mengalami perkembangan yang sesuai. Kesimpulan: stunting lebih banyak dibandingkan dengan anak yang tidak stunting dan tingkat perkembangan anak lebih banyak yang sesuai, tapi masih didapatkan anak yang mengalami penyimpangan perkembangan.
\end{abstract}

\section{Kata kunci: Stunting, Perkembangan, Pra sekolah}

\begin{abstract}
Toddlerhood is a period that is prone to experiencing problems of malnutrition, and development, it is because in infancy the body experiences relatively rapid growth and development compared to other periods. Screening for growth and development of pre-school children is an effort to improve the quality of children. The purpose of this activity is to identify the growth and development of pre-school children. The results of implementing TB / U growth screening (stunting) found the number of children who experienced stunting was 25 people (51\%), and normal as many as 24 people (49\%), while the developmental examination found 17 people (34.7\%) experienced deviations, 11 people (22.4\%) experienced doubtful developments and 21 people (42.9\%) experienced appropriate developments. Conclusion: more stunting than children who are not stunting and more appropriate level of child development, but there are still children who experience developmental deviations.
\end{abstract}

Keywords: Stunting, Development, Pre school

\section{PENDAHULUAN}

Masalah kekurangan gizi yang banyak mendapat perhatian akhir-akhir ini adalah masalah gizi kronis yang menggambarkan terhambatnya pertumbuhan karena malnutrisi dalam jangka panjang dimana 
anak pendek atau terlalu pendek untuk usianya. Keadaan ini di presentasikan dengan nilai $Z$-score tinggi badan menurut umur (TB/U) kurang dari -2 standar devisiasi (SD) berdasarkan standar pertumbuhan.

Ada beberapa dampak yang ditimbulkan stunting yaitu Dampak jangka pendek yang meliputi; Peningkatan kejadian kesakitan dan kematian, Perkembangan Kognitif, motorik, dan verbal pada anak tidak optimal, dan Peningkatan biaya kesehatan. Sedangkan Dampak jangka panjang meliputi; Postur tubuh yang tidak optimal saat dewasa (lebih pendek dibandingkan pada umumnya), Meningkatnya risiko obesitas dan penyakit lainnya, Menurunnya kesehatan reproduksi, Kapasitas belajar dan perfoma yang kurang optimal saat masa sekolah, dan Produktivitas kapasitas kerja yang tidak optimal (Kementerian Kesehatan, 2016).

Kualitas masa depan perkembangan anak ditentukan sejak dini, yakni sejak masa balita, dimana ketika balita terdapat perkembangan yang optimal maka periode selanjutnya akan cenderung terdapat pertumbuhan dan perkembangan yang baik (Ernawati, Muljati, Dewi, \& Safitri, 2014). Begitu pula ketika terdapat deteksi dini gejala stunting, maka dapat dilakukan penanganan sejak dini untuk memperbaiki pertumbuhan dan perkembangan balita. Hal ini bertujuan untuk menciptakan balita dengan fungsi motorik, kecerdasan, dan sosial yang baik, sehingga dapat meningkatkan kualitas hidup balita pada masa yang akan datang (Pantaleon, Hadi, \& Gamayanti, 2015).

Gangguan perkembangan, yang terlambat merupakan Dampak stunting tidak hanya dirasakan oleh individu yang mengalaminya, tetapi juga berdampak terhadap roda perekonomian dan pembangunan bangsa (Yulianti, et al., 2018). Hal ini karena sumber daya manusia stunting memiliki kualitas lebih rendah dibandingkan dengan sumber daya manusia normal. Anak yang pada masa balitanya mengalami stunting memiliki tingkat kognitif rendah, prestasi belajar dan psikososial buruk. Anak yang mengalami severe stunting di dua tahun pertama kehidupannya memiliki hubungan sangat kuat terhadap keterlambatan kognitif di masa kanak-kanak nantinya dan berdampak jangka panjang terhadap mutu sumber daya (Oktarina \& Sudiarti, 2013).

Data kejadian stunting di TK Pertiwi belum diketahui secara pasti angka kejadiannya. Pada studi awal penelitian Hasil data yang diperoleh jumlah keseluruhan siswa yang ada di TK Pertiwi 160 siswa. Terdiri dari 9 Rombel (A1-A3 dan B1-B6), tiap rombel terdiri dari 17-19 siswa. Untuk usia $48-59$ bulan terdapat 60 siswa. Pada saat pengukuran awal bersama guru dan kader diambil 10 siswa dan disimpulkan dari 10 siswa terdapat 7 orang siswa yang pendek (stunting). Informasi dari Guru, sebelumnya belum dilakukan pencatatan secara detail sehingga data kejadian stunting tidak tercatat secara jelas. Guru dan kader hanya melakukan pengukuran tapi tidak menyimpulkan berapa siswa yang pendek dan tinggi. Untuk data perkembangan guru melakukan penilaian perkembangan yang mencakup nilai-nilai agama, bahasa, kognitif, motorik, sosial emosional, fisik serta seni. Menurut dari guru anak didik 80\% perkembangan sesuai.

\section{TUJUAN}

1. Mengidentifikasi pertumbuhan anak (stunting)

2. Mengidentifikasi tingkat perkembangan anak

\section{PELAKSANAAN}

Pengabdian dilaksanakan di TK Pertiwi Majene pada tanggal 25 Juli 2019. Jumlah anak yang dilakukan skrining adalah 49 
orang. Terdiri dari Laki-laki sebanyak 25 orang $(51 \%)$ dan perempuan sebanyak 24 orang (49\%). Kegiatan pertama dengan melakukan permainan yang dapat menarik minat anak kemudian dilanjutkan dengan pengukuran tinggi badan dan pengukuran perkembangan

1. Mengidentifikasi pertumbuhan anak

Pengukuran tinggi badan dilakukan dengan menggunakan microtoice sejumlah 4 buah. Dalam hasil pengukuran berdasarkan TB/U didapatkan jumlah anak yang mengalami stunting adalah 25 orang (51\%), dan yang normal sebanyak 24 orang (49\%).

2. Mengidentifikasi

Tingkat

Perkembangan Anak

Pengukuran tingkat perkembangan meliputi, motorik kasar, motorik halus, personal sosial, dan Bahasa dengan menggunakan Kuisioner Pra Skrining Perkembangan (KPSP). Dalam pengukuran didapatkan data 17 orang (34,7\%) mengalami penyimpangan, 11 orang $\quad(22,4 \%) \quad$ mengalami perkembangan yang meragukan dan 21 orang (42,9\%) mengalami perkembangan yang sesuai.

\section{PEMBAHASAN}

Masa balita merupakan masa yang rawan mengalami masalah kurang gizi, hal tersebut dikarenakan pada masa balita tubuh mengalami pertumbuhan dan perkembangan yang relatif cepat dibandingkan masa-masa yang lain. Pertumbuhan dan perkembangan tubuh pada masa balita akan menentukan kualitas pertumbuhan di masa yang akan datang. Balita termasuk salah satu kelompok yang rawan gizi, sehingga ibu balita perlu memeriksakan anaknya ke posyandu karena posyandu merupakan farsilitas kesehatan dasar yang didalamnya juga ada Komunikasi, Informasi dan Edukasi (KIE) tentang kesehatan ibu balita yang di berikan oleh tenaga kesehatan.

Hasil dari pemeriksaan pertumbuhan menunjukkan masih terdapat balita yang memiliki pertumbuhan yang kurang baik yaitu masih terdapat stunting dengan jumlah $51 \%$. Nutrisi yang adekuat diperlukan dalam pertumbuhannya untuk mencapai tumbuh kembang yang optimal. Nutrisi terbaik yang diperlukan bayi pada 6 bulan pertama kehidupannya adalah ASI. Status gizi juga dipengaruhi oleh beberapa faktor diantaranya adalah pendidikan orang tua, dimana pendidikan orang tua yang tinggi dapat mengubah pola makan seseorang yang pada akhirnya nanti dapat berpengaruh terhadap status gizi keluarga termasuk anak. Hasil dari pemeriksaan perkembangan menunjukkan masih ditemukan adanya status meragukan dan penyimpangan balita. Perkembangan dapat dipengaruhi oleh beberapa faktor yaitu umur anak, pendidikan orang tua, penghasilan keluarga dan tempat tinggal. Pada penelitian diduga masih ditemukan tumbuh kembang balita yang kurang baik karena rata-rata pendidikan orang tua anak yaitu SMP sampai SMA/ sederajat sehingga masih diperlukan pemahaman yang cukup dan edukasi mengenai pentingnya stimulasi dan deteksi dini pada anak sehingga angka kejadian penyimpangan pada perkembangan anak dapat dikurangi.

Berdasarkan pedoman pelaksanaan Stimulasi, Deteksi, dan Intervensi Dini Tumbuh Kembang Anak (SDIDTK) bagi balita yang memiliki status perkembangan meragukan upaya yang harus dilakukan yaitu memberikan petunjuk pada ibu untuk melakukan stimulasi perkembangan pada anak lebih sering lagi dan melakukan pemeriksaan kesehatan untuk mencari adanya kemungkinan penyakit yang menyebabkan penyimpangan perkembangan. Meminta guru untuk melakukan stimulasi perkembangan pada 
anak terutama yang Meragukan dan Penyimpangan. Maka dari itu, disarankan pada guru agar tetap meningkatkan keaktifan dalam melakukan kegiatan belajar yang dapat menstimulasi tingkat perkembangan anak, dan menyiapkan fasilitas yang mendukung.

Anak pada periode pra sekolah perlu untuk mencapai tugas-tugas perkembangan mereka yang mencakup : keterampilan motorik, sosial dan bahasa. Pendidikan anak usia dini (PAUD) akan membantu pencapaian tugas-tugas perkembangan ini. Program PAUD mempunyai peran yang sangat penting untuk merangsang perkembangan anak. Orangtua dapat meyediakan permainan yang mendidik di rumah dan bagi petugas kesehatan harus aktif dalam memberikan screening pengembangan menggunakan DDST II untuk semua anak di masyarakat.

Pertumbuhan dan perkembangan dapat dioptimalkan dengan melakukan pemeriksaan secara berkala dan terus menerus. Faktor yang mempengaruhi keberhasilan stimulasi antara lain kemampuan dasar individu, kesehatan, keluarga, lingkungan, serta keadaan sosial ekonomi. Selain itu juga dipengaruhi oleh kapan waktu awal diberikan stimulasi, berapa lama, dan bagaimana cara melakukannya. Kemampuan perkembangan anak mempunyai ciri yang khas, yaitu mempunyai pola yang tetap dan terjadi secara berurutan, sehingga stimulasi dini yang dilakukan harus terarah dan ditekankan terlebih dahulu untuk pembentukan kemampuan dasar sebelum mengembangkan kemampuan kognitif dan perilaku yang lebih kompleks (Sugeng, Tarigan, \& Sari, 2019).

\section{KESIMPULAN}

Kesimpulkan yang didapatkan dari kegiatan pengabdian masyarakat di TK Pertiwi Saleppa Majene yakni:
1. Didapatkan pertumbuhan anak dalam hal ini stunting lebih banyak dibandingkan dengan anak yang tidak stunting

2. Didapatkan tingkat perkembangan anak lebih banyak yang sesuai, tapi masih didapatkan anak yang mengalami penyimpangan perkembangan.

\section{SARAN}

Perlu dilakukan kegiatan skring pertumbuhan dan perkembangan secara rutin dan melatih guru PAUD melakukan intervensi stimulasi perkembangan.

\section{UCAPAN TERIMA KASIH}

Ucapan terima kasih kami sampaikan kepada kepala sekolah beserta guru-guru TK Pertiwi Saleppa atas kerjasamanya, juga kepada pihak Fakultas Kesehatan Universitas Sulawesi Barat atas dukungannya.

\section{DAFTAR PUSTAKA}

Ernawati, F., Muljati, S., Dewi, M. ., \& Safitri, A. (2014). Hubungan panjang badan lahir terhadap perkembangan... (Ernawati F; dkk). Penel Gizi Makan, 37(2), 109-118.

Oktarina, Z., \& Sudiarti, T. (2013). Faktor risiko Stunting Pada Balita (24-59 Bulan) Di Sumatra. Jurnal Gizi Dan Pangan, 8(November), 175-180.

Pantaleon, M. G., Hadi, H., \& Gamayanti, I. L. (2015). Stunting berhubungan dengan perkembangan motorik anak di Kecamatan Sedayu , Bantul, Yogyakarta. Jurnal Gizi Dan Dietik Indonesia, 3(1), 10-21.

Sugeng, H. M., Tarigan, R., \& Sari, N. M. (2019). Gambaran Tumbuh Kembang Anak pada Periode Emas Usia 0-24 
Bulan di Posyandu Wilayah Kecamatan Jatinangor of age 0-24 Months in Posyandu Jatinangor Subdistrict. Jurnal Sistem Kesehatan, 4, 96-101.

Yulianti, N., Argianti, P., Herlina, L., Nur, S., \& Oktaviani, I. (2018). Analisis Pantauan Tumbuh Kembang Anak Pra sekolah (KPSP ) DI BKB PAUD Kelurahan Serdang Kecamatan Kemayoran Jakarta Pusat Periode
Oktober 2017. Indonesia Jurnal Kebidanan, 2(1), 45-52.

Kementrian Kesehatan Republik Tahun. (2016), Pedoman Pelaksanaan Stimulasi, Deteksi Dan Lntervensi Dini Tumbuh Kembang Anak Stimulasi, Deteksi Dan Lntervensi Dini Tumbuh Kembang Anak. : Bakti husada,. 